\title{
VAUGHN v. ROSEN: TOWARD TRUE FREEDOM OF INFORMATION
}

The fairness of the procedure through which a citizen may challenge his government's refusal to disclose information is a sensitive measure of the openness of a democratic society. Regarding the citizen's freedom of access to information, Attorney General Ramsey Clark noted:

Nothing so diminishes democracy as secrecy. Selfgovernment, the maximum participation of citizenry in affairs of state, is meaningful only with an informed public. How can we govern ourselves if we know not how we govern? ${ }^{1}$

In the wake of a growing undercurrent of congressional anxiety stemming from perceived agency excesses and noncompliance ${ }^{2}$ with the spirit of the Freedom of Information Act, ${ }^{3}$ the Court of Appeals for the District of Columbia in Vaughn v. Rosen ${ }^{4}$ scrutinized and significantly modified the nature of the procedure through which federal courts adjudicate government information denials under the FOIA. The plaintiff in Vaughn, a law professor researching government operations, had requested disclosure of Civil Service Commission reports evaluating the personnel management programs of other federal agencies. ${ }^{5}$ Upon the Commission's denial of his request, Vaughn brought suit under the FOIA, seeking injunctive relief ${ }^{6}$ to compel disclosure of the withheld information.

The Commission alleged in defense of its action that the personnel management reports were exempt from disclosure under provisions of the FOIA ${ }^{7}$ which protect (1) matter related

' U.S. Dep't of Justice, Attorney General's Memorandum on the Public Information Section of the Administrative Procedure Act iii (June 1967), quoted in, House Comm. oN Gov'r OPERATIONS, ADMINISTRATION OF THE FREEDOM OF INFORMATION ACT, H.R. REP. No. 1419, 92d Cong., 2d Sess. 5 (1972) [hereinafter cited as FOIA RePorT].

${ }^{2}$ See Vaughn v. Rosen, 484 F.2d 820, 826 (D.C. Cir. 1973). See also FOIA Report, supra note 1 , at 20-42.

35 U.S.C. $\$ 552(1970)$.

4484 F.2d 820 (D.C. Cir. 1973).

5 The contested reports issued by the Civil Service Commission's Bureau of Personnel Management, are each entitled Evaluation of Personnel Management. See 484 F.2d at 822.

${ }^{6} 5$ U.S.C. $\$ 552$ (a)(3) (1970) provides:

On complaint, the district court of the United States in the district in which complainant resides, or has his principal place of business, or in which the agency records are situated, has jurisdiction to enjoin the agency from withholding agency records and to order production of any agency records improperly withheld from the complainant. In such a case the court shall determine the matter de novo and the burden is on the agency to sustain its action.

7 Briefly, the Freedom of Information Act, 5 U.S.C. $\$ 552$ (1970), consists of three sections. Section 552(a) sets forth the general requirements for disclosure of most 
solely to internal agency personnel rules and practices, ${ }^{8}$ (2) inter-agency memoranda unavailable by law to a party other than an agency involved in litigation with the agency, ${ }^{9}$ and (3) personnel and medical files the disclosure of which would constitute an unwarranted invasion of personal privacy. ${ }^{10}$ After reviewing the preliminary papers filed in the case, including the broadly framed, nonspecific affidavit of the Director of the Bureau of Personnel Management Evaluation, the district court granted the Commission's motion for summary judgment. ${ }^{11}$

On appeal, the court of appeals found itself faced with a "scant record [which made] it impossible to determine if the information sought by appellant [was] indeed exempt from disclosure ...."12 Judge Wilkey, speaking for the court, remanded the case to the trial court with instructions, holding that a governmental agency must present a particularized justification for any assertion that information is exempt from disclosure under the FOIA. Such justification for the refusal to disclose must, according to Judge Wilkey, include an indexing system which subdivides the document in question into manageable parts cross-referenced to the relevant portions of the justification. ${ }^{13}$

government information, including publication or public availability of rules, procedures, substantive law, agency policy, final opinions, and administrative staff manuals. It provides for deletion of identifying details only to the extent necessary to prevent a clearly unwarranted invasion of personal privacy, and only if the justification for such deletion is fully set forth in writing. Each agency must make its records promptly available to any person without a showing of specific need. Finally, the section provides for injunctive relief when agency records are improperly withheld from a citizen, and prompt adjudication of such cases through docket precedence.

Section 552(b) exempts from disclosure material,

(l) specifically required by Executive order to be kept secret in the interest of the national defense or foreign policy;

(2) related solely to the internal personnel rules and practices of an agency;

(3) specifically exempted from disclosure by statute;

(4) trade secrets and commercial or financial information obtained from a person and privileged or confidential;

(5) inter-agency or intra-agency memorandums [sic] or letters which would not be available by law to a party other than an agency in litigation with the agency;

(6) personnel and medical files and similar files the disclosure of which would constitute a clearly unwarranted invasion of personal privacy;

(7) investigatory files compiled for law enforcement purposes except to the extent available by law to a party other than an agency;

(8) contained in or related to examination, operating, or condition reports prepared by, on behalf of, or for the use of an agency responsible for the regulation or supervision of financial institutions; or

(9) geological and geophysical information and data, including maps, concerning wells.

Section 552(c) repeats the policy that the FOIA does not authorize withholding of information or limit availability of records to the public except as stated therein. It also states that the FOIA does not confer authority to withhold information from Congress.

8 See 5 U.S.C. \& 552(b)(2) (1970).

${ }^{9}$ See id. § 552(b)(5).

${ }^{10}$ See id. \& 552(b)(6).

11484 F.2d at 823 .

12 Id. at 822 .

${ }^{13} I d$. at 826-28. 
This innovative procedural requirement illustrates the court's recognition that the proper determination of whether documents are exempt can be made only when the parties are able to engage in meaningful adversary debate. Of course, the enlightened adversary debate ensured by the Vaughn procedure may not in every case provide a judge with sufficient information to enable him to arrive at a reasoned decision. If it does not, however, recourse may be had to an in camera inspection facilitated by the evidence and arguments developed under the Vaughn procedure. Previously, the plaintiff's role had been necessarily limited due to his lack of knowledge regarding the actual nature and content of the withheld documents. By requiring a factually grounded and specifically indexed government justification, the court undoubtedly hoped to remove the plaintiffs handicap of blind reliance upon generalized government defenses which may or may not fairly characterize each part of the information sought, in litigation over documents he has never seen. ${ }^{14}$

The courts have had difficulty in effectuating a proper relationship ${ }^{15}$ between the litigants to comport with the FOIA's requirements of de novo review and governmental justification for the refusal. ${ }^{16}$ In recent cases the courts have generally either conducted in camera inspection of the documents ${ }^{17}$ or adjudicated the dispute solely in reliance upon the briefs and arguments of the parties. ${ }^{18}$ For reasons discussed below, Vaughn replaces these methods with requirements of government specificity and indexing designed to lessen reliance upon unenlightened in camera inspection, enhance the adversary process between citizen and government, and provide a meaningful record for appellate review. This Comment will examine

14 "This lack of knowledge by the party seeking disclosure seriously distorts the traditional nature of our legal system's form of dispute resolution." Id. at 824 .

${ }_{15} \mathrm{~A}$ proper relationship will be one which curtails indiscriminate government secrecy and fosters the ability of citizens to assert with confidence their "right to know what [their] Government is doing." Senate Comm. ON THE Judiciary Clarifying and Protecting The Right of THE PUBlic to Information, and for OTHER PURPoses, $S$. REP. No, 813, 89th Cong., Ist Sess. 5 (1965) [hereinafter cited as Right to INFORMation REPORT].

The position of the judge in our system of civil procedure is adjudicative, not adversary. Within these parameters a balance must be struck which permits adjudication on the merits while preserving the confidentiality of information which may be properly withheld, without being excessively costly in terms of court time or legal fees.

${ }^{16}$ See note 6 supra.

${ }^{17}$ See, e.g., Cuneo v. Schlesinger, 484 F.2d 1086 (D.C. Cir. 1973), remanding 338 F. Supp. 504 (D.D.C. 1972); Bristol-Myers Co. v. FTC, 424 F.2d 935, 939 (D.C. Cir.), cert. denied, 400 U.S. 824 (1970); Ackerly v. Ley, 420 F.2d 1336, 1341 (D.C. Cir. 1969); Fisher v. Renegotiation Bd., 355 F. Supp. 1171 , 1172 (D.D.C. 1973), remanded from 473 F.2d 109 (D.C. Cir. 1972); Stokes v. Hodgson, 347 F. Supp. 1371, 1373 (N.D. Ga. 1972), aff'd sub nom. Stokes v. Brennan, 476 F.2d 699 (5th Cir. 1973); Benson v. GSA, 289 F. Supp. 590, 591 (W.D. Wash. 1968), aff'd, 415 F.2d 878 (9th Cir. 1969).

${ }^{18}$ See, e.g., Grumman Aircraft Eng'r Corp. v. Renegotiation Bd., 482 F.2d 710 (D.C. Cir. 1973), affg 325 F. Supp. 1146 (D.D.C. 1971); Getman v. NLRB, 450 F.2d 670 (D.C. Cir.), stay denied, 404 U.S. 1204 (1971); Consumers Union of U.S., Inc. v. Veterans Admin., 301 F. Supp. 796 (S.D.N.Y. 1969), appeal dismissed, 436 F.2d 1363 (2d Cir. 1971). 
Vaughn's assumptions, precedents upon which it relies, and its probable effect upon future FOIA litigation.

\section{The Nature of FOlA Adversary Proceedings}

\section{A. Construction of the Act in Theory and in Practice}

The Freedom of Information Act is a deceptively simple document, which in its short history has been the vehicle for several hundred lawsuits ${ }^{19}$ to enjoin government agencies from withholding information. The Act forcefully states the congressional intent that the public be given access to all information necessary for knowledge of government activities, except specifically protected information or reports which Congress has exempted through the Act or the Executive has determined should be kept confidential in the interest of national security. ${ }^{20}$ The FOIA replaced the information section of the Administrative Procedure Act," ${ }^{21}$ which had been perceived as "full of loopholes which allow[ed] agencies to deny legitimate information to the public,"22 and also as having become "the Government's major shield of secrecy."23

Significantly, the FOIA is a general mandate for disclosure of information with certain enumerated, narrow exceptions. ${ }^{24}$ This construction crucially colors the theory of FOIA litigation; the party requesting government information is presumed entitled to it, and the burden of proof falls upon the agency to sustain its denial ${ }^{25}$ under one or more of the specific exemptions. ${ }^{26}$

An agency characterization of the contents of a withheld document as falling within one of the exempt categories often leads to a factual dispute regarding the contents of the document. The plaintiff is ill-equipped to engage in any such debate. The scales are tipped dramatically in favor of the government, which may base its arguments upon intimate knowledge of the document, whereas the plaintiff's arguments must be based almost exclusively upon the information that can be gleaned

${ }^{19}$ See FOIA REPORT, supra note 1 , at 70.

20 See House Comm. on Gov't Operations, Clarifying and Hrotecting the Right of the Public to Information, H.R. Rep. No. 1497, 89th Cong., 2d Sess. 9-11 (1966) [hereinafter cited as Ptiblic Right RePort]; Right to INFORMation REPORT, supra note 15 , at $5-6$.

${ }_{21}$ Act of June 11, 1946, ch. 324, § 3, 60 Stat. 238.

22 RIGHT TO INFORMATION REPORT, supra note 15 , at 3.

23 Public Right Report, supra note 20 , at 12.

${ }^{24}$ See Getman v. NLRB, 450 F.2d 670, 672 (D.C. Cir.), stay denied, 404 U.S. 1204 (1971); Bristol-Myers Co. v. FTC, 424 F.2d 935, 938 (D.C. Cir.), cert. denied, 400 U.S. 824 (1970). See also note 7 supra.

${ }_{25}$ See 5 U.S.C. \$ 552(a)(3) (1970) (quoted in note 6 supra).

${ }^{26}$ See 5 U.S.C. \$\$ 552(b)(1)-(9) (1970) (quoted in note 7 supra). But see note 50 infra, regarding the qualified nature of the factual dispute under $\$ 552(b)(1)$ (national security) and possibly under $\S 552(\mathrm{~b})(3)$ (exempt from disclosure under another statute). 
from the description of the document supplied by his adversary, the government. It is entirely unrealistic to assume that a procedure in which one party is denied accurate knowledge of the subject matter in issue can produce effective adversary debate. Absent the specific justification and indexing of documents mandated by Vaughn, the plaintiff is in reality required to reverse roles and carry the burden of proving that the document is not exempt, contravening the very purpose and structure of the FOIA.

Assuming, however, that the factual issue regarding the contents of the documents has been resolved or that the government has accurately summarized the contents, a legal issue remains. Do the contents fall within one of the exemptions of the Act? The exact scope of the various exemptions is so unclear ${ }^{27}$ that carefully tailored, narrow arguments are necessary to determine whether a document is exempt from disclosure. The narrow nature of the arguments can be demonstrated by several examples of disputes regarding the nature of withheld documents. Disputes have arisen over whether information consists of exempt opinions or disclosable facts; ${ }^{28}$ exempt internal memoranda or disclosable final work product; ${ }^{29}$ exempt law enforcement files or disclosable staff manuals; ${ }^{30}$ documents discoverable or nondiscoverable in litigation with the agency; ${ }^{31}$ files which if disclosed would unwarrantedly invade personal privacy; ${ }^{32}$ and exempt and nonexempt materials inextricably

${ }^{27}$ The wealth of fine commentary concerning FOIA exemptions is helpful in understanding the dependence in each case upon the particular nature of the withheld information. See, e.g., Davis, The Information Act: A Preliminary Analysis, 34 U. CHI. L. REv. 761 (1967); Note, Developments Under the Freedom of Information Act-1972, 1973 Duke L.J. 178; Note, The Freedom of Information Act-The Parameters of the Exemptions, 62 GEo. L.J. 177 (1973); Note, The Freedom of Information Act and the Exemption for Intra-Agency Memoranda, 86 Harv. L. Rev. 1047 (1973).

Such analyses make an implicit assumption that the facts of the case are known and thus that fine distinctions can be made in argument on the merits as in most ordinary litigation. Vaughn's challenge to this assumption rests upon the nature of FOIA adversary procedure and the meaning and intent of the FOIA. This Comment therefore does not deal with the specific exemptions, but focuses upon the various processes of adjudicating the merits of FOIA claims and defenses.

${ }^{28}$ See, e.g., EPA v. Mink, 410 U.S. 73, 89 (1973); Vaughn v. Rosen, 484 F.2d 820 (D.C. Cir. 1973); Consumers Union of U.S., Inc. v. Veterans Admin., 301 F. Supp. 796, 804-06 (S.D.N.Y. 1969), appeal dismissed, 436 F.2d 1363 (2d Cir. 1971).

${ }^{29}$ See, e.g., Grumman Aircraft Eng'r Corp. v. Renegotiation Bd., 482 F.2d 710 (D.C. Cir. 1973), aff'g 325 F. Supp. 1146 (D.D.C. 1971); Tennessean Newspapers, Inc. v. FHA, 464 F.2d 657, 660 (6th Cir. 1972); Fisher v. Renegotiation Bd., 355 F. Supp. 1171, 1175 (D.D.C. 1973), remanded from 473 F.2d 109 (D.C. Cir. 1972).

${ }^{30}$ See, e.g., Stokes v. Hodgson, 347 F. Supp. 1371 (N.D. Ga. 1972), affd sub nom. Stokes v. Brennan, 476 F.2d 699 (5th Cir. 1973); Philadelphia Newspapers, Inc. v. HUD, 343 F. Supp. 1176, 1178 (E.D. Pa. 1972); Cuneo v. Laird, 338 F. Supp. 504 (D.D.C. 1972), rev'd sub nom. Cuneo v. Schlesinger, 484 F.2d 1086 (D.C. Cir. 1973).

${ }_{31}$ See Ackerly v. Ley, 420 F.2d 1336 (D.C. Cir. 1969); Benson v. GSA, 289 F. Supp. 590 (W.D. Wash. 1968), aff'd, 415 F.2d 878 (9th Cir. 1969).

${ }^{32}$ See Getman v. NLRB, 450 F.2d 670, 674-77 (D.C. Cir.), stay denied, 404 U.S. 1204 (1971). 
intertwined in the same document. ${ }^{33}$ The precision of focus necessary to the proper resolution of the legal issues in FOIA disputes obviously disadvantages a plaintiff who is not completely informed of the nature of each document.

Given the range of exemptions arguably applicable to any controverted document, it is not surprising, as Vaughn notes, ${ }^{34}$ that government agencies recognize that they lose little or nothing by claiming overly broad exemptions for documents in their possession. ${ }^{35}$ Since the dispute often turns upon the precise content of each document, and the plaintiff is unable to argue on the basis of complete knowledge, essential unfairness inheres in the litigation, eroding the very purpose of the FOIA. ${ }^{36}$

\section{B. Court Imposed FOIA Procedures}

Prior to Vaughn, little attention was given to the issue of the adequacy of adversary proceedings in FOIA litigation. This inattention seems surprising since, as the Vaughn opinion states: "[T]he party with the greatest interest in obtaining disclosure is at a loss to argue with desirable legal precision for the revelation of concealed information." ${ }^{37}$ In other words, how can the citizen argue that the government may not deny his right to obtain certain information under the FOIA if he remains uncertain of what the precise information is?

The plaintiff in Vaughn presents an excellent concrete illustration of these difficulties. One of the arguments against disclosure asserted by the Civil Service Commission was that its personnel management evaluation reports contained "[n]ot only the names and job descriptions but actual case histories dealing with job performance" of some personnel in each federal agency studied..$^{38}$ This general claim of exemption contained no details or references to any particular document which, if disclosed, would constitute an unwarranted invasion of privacy.

Given so little information relating to the actual content of the documents, plaintiff Vaughn could only respond to the court that the record in the case "contains no proof ... that materials contained in the reports are of a personal nature and that

${ }^{33}$ See, e.g., EPA v. Mink, 410 U.S. 73, 78 (1973); National Cable Television Ass'n, Inc. v. FCC, 479 F.2d 183 (D.C. Cir. 1973); Fisher v. Renegotiation Bd., 473 F.2d 109, $112-13$ (D.C. Cir. 1972); Sterling Drug, Inc. v. FTC, 450 F.2d 698, 704 (D.C. Cir. 1971); Soucie v. David, 448 F.2d 1067, $1077-79$ (D.C. Cir. 1971).

${ }^{34}$ See 484 F.2d at 826.

35 "[C]ourts must beware of "the inevitable temptation of a governmental litigant to give [this exemption] an expansive interpretation in relation to the particular records in issue." "Soucie v. David, 448 F.2d 1067, 1078 (D.C. Cir. 1971), quoting Ackerly v. Ley, 420

F.2d 1336, 1341 (D.C. Cir. 1969).

${ }^{36}$ See generally note 7 supra.

37484 F.2d at 823 .

${ }^{38}$ Brief for Appellees at 17, Vaughn v. Rosen, 484 F.2d 820 (D.C. Cir. 1973). 
disclosure would be clearly unwarranted."39 It was impossible to argue on the merits of the information actually contained in the reports. Also, the plaintiff recognized but could not prove the likelihood that highly personal portions could be deleted, and access to the bulk of the material granted. Perhaps sensing the futility of argument without knowledge of what the reports actually said about individual personnel, plaintiff suggested on appeal that in camera inspection be ordered to settle the dispute. ${ }^{40}$

The first FOIA case decided by the Supreme Court was Environmental Protection Agency v. Mink, ${ }^{41}$ involving nine documents prepared for the President relating to a planned underground nuclear explosion in Alaska. Six of the documents were alleged to fall within the national security exemption and the Court accepted as sufficient to establish the exemption an affidavit stating that they were classified as Secret or Top Secret. ${ }^{42}$ The key aspect of Mink relating to Vaughn is the philosophical assumptions underlying its view of the lower court's order ${ }^{43}$ directing in camera inspection of three documents purportedly exempt as interagency memoranda or letters used in the decisionmaking process. The Court, noting that the remand directed the trial judge to disclose only such factual material as is not "intertwined with policymaking processes" so that the integrity of the "policymaking decisional processes intended to be protected by this exemption" would not be violated, affirmed this specific use of in camera inspection. ${ }^{44}$

Recognizing the potential burdens of in camera review if routinely applied in FOIA cases, the Court stated that the in camera procedure need not be automatic. Before such inspection is ordered in an FOIA case, the majority in Mink directed:

An agency should be given the opportunity, by means of detailed affidavits or oral testimony, to establish to the satisfaction of the District Court that the documents sought fall clearly beyond the range of material [which is subject to disclosure]..$^{45}$

Thus, the Mink procedure for dispute settlement involves the judge as an adversary, probing the substance of defendant's arguments for exemption. The Court envisioned a two step process in which the defendant first argues to the judge, attempt-

${ }^{39}$ Reply Brief for Appellant at 8, Vaughn v. Rosen, 484 F.2d 820 (D.C. Cir. 1973).

${ }^{40} I d$. at 9.

41410 U.S. 73 (1973), rev'g छ remanding 464 F.2d 742 (D.C. Cir. 1971).

42 Id. at 84; see note 51 infra.

43464 F.2d at $746-47$.

4410 U.S. at 92 .

${ }^{45} \mathrm{Id}$. See also id. at 95-96 (Brennan, J., concurring in part). 
ing to satisfy him that the material is exempt. If the judge remains unsatisfied after the defendant's argument, he may inspect the material, or representative samples provided by the defendant, in camera. Under such a system an onerous burden falls upon the judge, who must determine for himself whether the information sought should be disclosed. The plaintiff is not considered; Mink prescribes an adversary contest between judge and government, not between the parties.

Vaughn's remedial procedures must be tested against Mink's prescription of "detailed affidavits and oral testimony." The Vaughn court's refusal to accept an affidavit stating that the evaluations were not subject to disclosure under three FOIA exemptions, ${ }^{46}$ is not inconsistent with the Mink acceptance of an affidavit to establish a national security exemption -due to the dissimilarity of the national security exemption and other FOIA exemptions. ${ }^{47}$ Vaughn is a reasoned elaboration upon the language in Mink calling for detailed affidavits, providing a similar but more precisely focused procedural framework within which to test the adequacy of the government's defenses. The Court certainly did not establish mandatory FOIA procedures in Mink, rather it briefly described a framework sufficient to deal with the complex case at hand. Thus, the justification/index procedure of Vaughn falls squarely within the underlying philosophy of Mink, admirably serving the function of enabling the trial judge to form an accurate picture of the documents in question without the need for actual access to them.

Vaughn has thus expanded the Mink mandate of detailed affidavits and oral testimony to include a particularized justification coupled with an indexing system, permitting the judge to weigh the merits of the defendant's specific refusal justification against the narrowly tailored arguments of the plaintiff focused upon each segment of the documents. In short, Vaughn has transformed the inquisitorial procedure envisioned by Mink into a more effective adversary procedure, which shifts much of the burden of testing defendant's defenses from the trial judge to the plaintiff, who is likely to be more adequately prepared and equipped to effectively perform this role. Those instances in which in camera inspection will be necessary should

46484 F.2d at $482-83$.

${ }^{47}$ The de novo matter to be determined in the national security exemption is "whether in fact the President has required by Executive Order that the documents in question are to be kept secret." 410 U.S. at 95 (Stewart, J., concurring) (noting that the same limitation inheres in the $\$ 552$ (b)(3) exemption for materials "specifically exempted from disclosure by statute.") In determinations regarding other exemptions, however, the factual disputes about documentary content are open to full challenge with the burden upon the agency to sustain its action. See 5 U.S.C. \$ 552(a)(3) (1970). Vaughn's rejection of the affidavit is thus consistent with Mink, as the allegations in the defendant's affidavit failed to establish an exempt status satisfactory to the court. 
be drastically reduced by the Vaughn procedure, responding directly to the caveat in Mink concerning the burdens of routine in camera inspection. Vaughn emphasizes specificity to a greater extent than Mink, imposing a more onerous burden of proof upon the defendant, as the statute mandates, granting the plaintiff a more active, assertive role in the litigation, and conserving scarce judicial resources.

Vaughn's adversary procedure with its emphasis on enlightened plaintiff participation more effectively complies with the mandate of the Act-requiring the government to meet the burden of proof to sustain its refusal to disclose material-than does the limited inquisitorial procedure envisioned by the skeletal framework suggested in Mink. If pursuant to the Vaughn procedure the nature of the particular documents is disclosed by the defendant agency, the plaintiff-who often possesses comprehensive knowledge regarding the purpose and functions of that agency ${ }^{48}$ - can argue with specificity concerning how that purpose or those functions relate to the documents in question. This should significantly increase the probability that the trial judge will arrive at a proper resolution of the legal issues.

The naked procedure of conclusory argument followed by in camera inspection has been previously employed to test the legitimacy of the internal personnel rules exemption, ${ }^{49}$ the interagency memoranda exemption, ${ }^{50}$ and government allegations under other FOIA exemptions. ${ }^{51}$ These proceedings consumed valuable time of the trial judge who probably lacks the expertise of the plaintiff, and whose efforts might more profitably be employed in other matters.

The real burden under this usual procedure of conclusory argument followed by in camera inspection falls upon the plaintiff who must argue without the guidance of detailed defense analysis, and the judge who conducts the inspection in camera without benefit of precise, intelligent argument by the parties.

4s For example, Vaughn is an expert on the operations of the Civil Service Commission, having written a comprehensive study of it entitled The Spoiled System. Reply Brief for Appellant at 8, Vaughn v. Rosen, 484 F.2d 820 (D.C. Cir. 1973).

${ }^{49}$ See Stokes v. Hodgson, 347 F. Supp. 1371 (N.D. Ga. 1972), aff d sub nom. Stokes v. Brennan, 476 F.2d 699 (5th Cir. 1973).

${ }_{50}^{\circ}$ See Bristol-Mfyers Co. v. FTC, 424 F.2d 935,939 (D.C. Cir.), cert. denied, 400 U.S. $824(1970)$.

51 The Supreme Court announced a limitation on the use of in camera inspection in Mink. The Court forbade in camera inspection of a document to fall under the exemption for matters "specifically required by Executive order to be kept secret in the interest of national defense," 5 U.S.C. \$ 552(b)(1) (1970), provided that the government demonstrates that such classification was made pursuant to a specific Executive Order. 410 U.S. at 83. The Court found that the government had satisfied its burden with respect to 6 documents in a report to the President regarding plans for the 1971 Cannikin nuclear test at Amchitka Island, Alaska. An affidavit alleging that each of the documents was classified Top Secret or Secret pursuant to Exec. Order No. 10501, 18 Fed. Reg. 7049 (1953), was sufficient to establish the exemption. 
Vaughn casts serious doubt on whether a judge can make a meaningful decision under such circumstances. Inspection of the raw documents in camera without the benefits of enlightened debate was characterized in Vaughn as "burdensome, . . . conducted without benefit of criticism and illumination by a party with the actual interest in forcing disclosure." 52 It is an unfortunate misuse of scarce judicial resources to impose this duty upon a judge to thoroughly evaluate the many elements of a complex or unique set of documents. ${ }^{53}$ Government agencies, however, possess ample resources to evaluate and explicate the nature of the documents which they have themselves prepared.

Finally, bare in camera inspection often fails to produce an adequate record for appellate review. When a judge completes his necessarily rapid inspection of documents, the court's findings frequently must be stated in conclusory terms. This lack of a detailed record compounds the problems of an appellate court reviewing the factual determination made below. ${ }^{54}$

52484 F.2d at 825 .

${ }^{53}$ Recent congressional hearings have examined proposals to amend the Freedom of Information Act in order to promote the responsiveness of the executive agencies and courts to citizen requests for information. One bill, S. 1142, 93d Cong., Ist Sess. (1973), would compel in camera examination of the contents of any records of which disclosure is sought, to determine if such records or any part thereof could be withheld under the FOIA exemptions. $I d$. $\S \mathrm{I}(\mathrm{d})(\mathrm{l})$. The statutory mandate for direct scrutiny in all FOIA cases was seen by several witnesses as a response to Mink to insure that inspection in camera could not be an abuse of discretion. See Hearings on S. 1142 Before the Subcomm. on Administrative Practice and Procedure of the Senate Comm. on the Judiciary, 93d Cong., 1st Sess., vol. 2 , at $36,65,155$ (1973).

As demonstrated in the text, automatic in camera inspection, without more, is an insufficient remedy for the procedural problems of FOIA litigation. A more desirable solution in most FOIA cases would require the government to file a detailed justification statement and index, as outlined in Vaughn, coupled with an adversary hearing and trial if necessary. In camera inspection should be explicitly reserved as a matter of full discretion for those instances in which the judge cannot otherwise decide the issue.

In FOIA cases touching upon national security issues under 5 U.S.C. $\$ 552(b)(1)$ (1970), in camera scrutiny of documents could be limited by the extent of congressional deference, either as constitutionally required or as a matter of Congress' own choice, toward the present executive document classification mechanism under Exec. Order No. 10501, 18 Fed. Reg. 7049 (1953). However, as that system undergoes intensive congressional scrutiny, see, e.g., Hearings on H.R. 5425 Before the Subcomm. on Foreign Operations and Government Information of the House Comm. on Government Operations, 93d Cong., 1st Sess. (1973), it should be recognized that complete de novo inspection to review the validity of the actual security classification of each document would essentially eliminate the executive classification system in FOIA cases.

54484 F.2d at 825 .

Vaughn's characterization of the hazards of unenlightened in camera inspection is grounded in recent cases. See, e.g., Ackerly v. Ley, 420 F.2d 1336 (D.C. Cir. 1969); Cuneo v. Laird, 338 F. Supp. 504 (D.D.C. 1972), rev'd sub nom. Cuneo v. Schlesinger, 484 F.2d 1086 (D.C. Cir. 1973).

The court in Ackerly was concerned with the inspection of medical records used in an FDA study recommending the banning of carbon tetrachloride. It complained in remanding:

Our difficulty at this point resides in the fact that it was the District Court, and not this court, which examined the disputed records in camera; and we cannot tell from its abbreviated and tangential comments whether its decisional approach was adequately rooted in the legislative policies underlying the exemp- 


\section{FUTURE IMPACT of Vaughn v. Rosen}

Although adopted so far in only the District of Columbia Circuit, Vaughn's impact upon future FOIA litigation should be extremely significant not only because of its precedential effect upon other circuits, but because over half of the FOIA appeals are handled by that court. ${ }^{55}$ The District Court for the District of Columbia may take jurisdiction whenever the plaintiff resides or has his principal place of business in the District, or when the agency's records are located there. ${ }^{56}$

\section{A. Requisite Specificity}

The amount of specificity required by Vaughn in the government's justification should vary depending upon the complexity of the documents and scope of the request in each case. Vaughn provides very flexible criteria, requiring only "a relatively detailed analysis in manageable segments," ordinarily composed "without excessive reference to the actual language of the document" where the nature of the secret information would be compromised. ${ }^{57}$ An index must accompany the justification to indicate which exemptions the government relies upon to sustain the withholding of each segment of information. Subsequent litigation will undoubtedly add some flesh to this skeletal statement of the Vaughn requirement.

In the first FOIA appeal decided after Vaughn, the District of Columbia Circuit in Cuneo v. Schlesinger ${ }^{58}$ found that despite in camera inspection, the record granting the government's motion for summary judgment was insufficient to meet the Vaughn specificity and indexing requirements. The court was concerned that disclosable substantive information, policy, and guidelines used in dealing with government contractors might be intermingled with exempt internal personnel rules and memoranda within the agency manual ${ }^{59}$ which was sought. The court therefore remanded, requiring the government to "correlate its reasons for claiming that the various portions of the Manual should not be disclosed ...."60

tion. . . . There is no reference whatsoever to any one of the statutorily enumerated exemptions, including Exemption (5) primarily relied on by the Commissioner here.

420 F.2d at 1341 .

5s The D.C. Circuit had decided 9 of the 17 FOIA appeals through early 1972. See FOIA REPORT, supra note 1, at 70-71. Subsequent experience reflects, if anything, an increase in this proportion.

${ }^{56} 5$ U.S.C. $\$ 552(a)(3)(1970)$.

57484 F.2d at $826-27$.

${ }^{58} 484$ F.2d 1086 (D.C. Cir. 1973), rev'g sub nom. Cuneo v. Laird, 338 F. Supp. 504 (D.D.C. 1972).

${ }_{59}$ The Defense Contract Audit Agency Manual (1965), which guides government agents in selective auditing of defense contractors, was sought. Id. at 1088 .

${ }^{60} I d$. at 1092. 
The lack of a suitable record upon appeal resulted from the appellant's request for total access opposed by the government's claim of blanket exemption, ${ }^{61}$ precisely the situation described in Vaughn. The implication in Cuneo, echoing Vaughn, is that the full adversary process is required before an in camera inspection of the documents can meaningfully take place.

In deciding upon the requisite degree of specificity in a particular case, a district judge should consider carefully the purposes for which the requirement was adopted. The justification should be sufficiently factual so that the parties can engage in meaningful debate for the benefit of the court. The analysis must be detailed enough to provoke argument which carefully defines the parameters of the dispute and leads to prompt judgment or in unusual or highly complex cases to enlightened in camera inspection. If it is not possible for both parties to argue intelligently upon the merits of each segment of allegedly exempt material, the defense justification should not satisfy Vaughn.

\section{B. Delay, Costs, and Burden}

Unnecessary delay by the government in responding to FOIA requests has been frequent at both administrative and judicial levels. ${ }^{62}$ In view of past practices of delay and obfuscation in FOIA litigation it is reasonable to inquire whether the government is likely to accept in good faith its new burdens under Vaughn. Unfortunately, because courts have not exerted pressure upon the government to discharge the congressional mandate of swift process in FOIA suits, ${ }^{63}$ a government defense inadequate under Vaughn may not be analyzed critically enough to insure compliance with Vaughn's mandate of adversary process. Unless FOIA plaintiffs persuade the trial courts that the Vaughn procedure is not only equitable, but essential to remedy inherent FOIA weaknesses, those seeking information may find it difficult to escape the all too familiar time consuming, costly

${ }^{61} I d$. at 1091.

${ }_{62}$ Specific practices are summarized in FOIA REPORT, supra note 1, at 20-42, 70-77. See also Tennessean Newspapers, Inc. v. FHA, 464 F.2d 657, 659 (6th Cir. 1972) (agency provided citizen with illegible copies of appraisal information): Ackerly v. Ley, 420 F.2d 1336, 1340 (D.C. Cir. 1969) (agency frustrated plaintiffs access to information used in proposing a ban on carbon tetrachloride). For an illustrative description of prelitigation avoidance techniques, see Nader, Freedom From Information: The Act and the Agencies, 5 Harv. Giv. Rights-Giv. Lib. L. Rev. 1, 5-15 (1970).

63 "A statistical analysis of 33 FOI Act suits filed in the U.S. District Court for the District of Columbia shows that it took an average of 68 days for the government to file a responsive pleading and an average of 167 days before the [case] was decided by the court." FOIA REPORT, supra note 1 , at 76 . This indicates court accession not only to noncompliance with the 60 day maximum for responsive pleading, see FED. R. Crv. P. 12(a), but also to violation of the Act's command that actions shall be "expedited in every way." 5 U.S.C. § 552(a)(3) (1970). 
pattern of insufficient trial analysis, appellate review, and remand.

The Vaughn requirements may well be urged, ironically, as a justification for further delay to permit thorough defense preparation. Such an argument should be received with disfavor and scrutinized carefully because Congress, although recognizing the increased burden placed upon the government to support an information refusal, has commanded expeditious process in FOIA litigation. ${ }^{64}$ The heavy burden upon the agencies was noted and approved in Wellford $v$. Hardin ${ }^{65}$ in which the court stated that the Act was "not designed to increase administrative efficiency, but to guarantee the public's right to know how the government is discharging its duty to protect the public interest." 66

Where proper defense is not timely made or an agency purposefully pursues dilatory tactics, the court should consider whether the public interest in rapid access to government information justifies summary judgment for the plaintiff. Such a remedy, although seemingly Draconian, may be the only effective means to avoid frustration of the purposes of the FOIA and negation of the benefits of the Vaughn procedure.

The imposition of this greater burden may have a collateral beneficial result as an agency may be less apt to litigate exemptions of questionable validity and thus be more disposed toward disclosure. Rather than involving citizens in costly litigation, the government may be more likely to settle the average cases by granting disclosure at the agency level and concentrate its efforts upon defending those cases in which an arguably meritorious exemption exists. ${ }^{67}$

\section{When Should Vaughn Be Inapplicable?}

Specific justification and indexing should not be required in all FOIA cases, but only in those in which there is a factual dispute regarding the nature of the information withheld. Agreement by the parties regarding the exact type of information should result in a stipulation of facts in some cases, enabling the court to pass judgment quickly upon the merits of the parties' legal arguments. Such a situation arose, for example, in

${ }^{64}$ Id. If the Vaughn procedure becomes widely accepted, perhaps the FOIA should be amended to require that agencies prepare in advance and keep available the justification material for any class of documents they do not wish to disclose. Such a requirement would be consistent with the basic presumption of the Act that information is not exempt unless specifically so provided.

${ }_{65} 444$ F.2d 21 (4th Cir. 1971).

${ }^{66} I d$. at 24.

${ }^{67}$ Data indicate that government agencies often withhold information from the public when there is little hope of success in litigation. The government has lost 3 of every 4 FOIA court challenges. See FOIA REPORr, supra note 1, at 72. 
Getman v. $N L R B,{ }^{68}$ in which the parties agreed that the withheld list contained only the names and addresses of employees who participated in a series of union elections monitored by the NLRB. Thus, the legal issue of the parameters of the exemption for invasion of privacy could be argued intelligently without the time-consuming indexing and preparation of a detailed refusal justification. Thus, as the Vaughn procedures will not be necessary to ensure meaningful adversary debate in all factual situations, the courts should make every effort to articulate more precisely those situations in which the procedures will be necessary and at what stage of the litigation the government will be required to file its specific refusal justification.

\section{Conclusion}

The particularized justification for refusal cross-referenced to the relevant segments of the withheld material prescribed by Vaughn in FOIA cases, as an elaboration upon the requirements of Mink, should remedy an inherent weakness in the present procedure by which a citizen seeks information regarding the operation of his government. The present procedure of conclusory argument followed by in camera inspection of the material in question, even when supplemented by the detailed affidavits and oral testimony mandated by the Supreme Court in Mink as a prerequisite to such inspection, fails to provide meaningful adversary debate to aid the judge in his determination of the merits of the dispute. Vaughn's requirement of a precise refusal justification cross-referenced to specific segments of the allegedly exempt material provides plaintiffs with the knowledge to engage in meaningful adversary debate for the enlightenment of the trial judge, effectively places the burden of proof on the government as the Act mandates, conserves valuable judicial resources previously squandered on unenlightened in camera inspection, and ensures an adequate record for appellate review. In short, Vaughn has revitalized the presumption of the FOIA that, unless specifically exempt, government documents should be available to the public. 